\title{
A Jurisprudential Overview of the Legal Obstacles to the Creation of New Local Governments in Nigeria Since 1999*
}

\author{
Dr. Benjamin O. Igwenyi \\ Associate Professor of Law, Department of Public And Private Law, Ebonyi State University, P.M.B 053, \\ Abakaliki, Nigeria \\ Onu J. Onwe \\ Department of Public and Private Law, Ebonyi State University, P.M.B 053, Abakaliki, Nigeria \\ Nnamdi. P. Ben-Igwenyi, \\ PUNUKA Law Firm, Plot 45 Oyibo Adjarho Street, Lekki Peninsula Phase I, Lagos, Nigeria
}

\begin{abstract}
Local Governments constitute the last level of government in all countries where they exist and form the link between the grassroot, the State Governments (Regional) and the Federal Government (Central). A properly managed Local Government system will bring development to the rural areas of the country, train up-coming politicians for participating in national politics and create jobs for the young and the old. Local Governments had existed in Nigeria before colonialism and had continued to be after independence in 1960 where each Region adopted her own system of Local Government until 1976 when the Federal Military Government decreed Unified Local Government System in the whole country. The Constitution of the Federal Republic of Nigeria, 1979 adopted Unified Local Government System in section 7 of the Constitution just as the 1999 Constitution in section 8 provided for very stringent procedure for the creation of Local Governments amongst other obnoxious provisions which have made nonsense of the possibility of creating new Local Governments in the country. This paper argues that looking at what obtains in established democracies such as U.S.A, Brazil, India etc; that time has come for the obstacles stopping the creation of new Local Government Areas in Nigeria to be removed from the Constitution to allow this important level of government to be multiplied in the country for expanded and even development of the nation.
\end{abstract}

Keywords: Local government, obstacles, constitutional amendments, creation, even development.

DOI: $10.7176 / J L P G / 90-03$

Publication date:October $31^{\text {st }} 2019$

\subsection{Introduction}

Local Governments constitute the last level of government in all countries where they exist and form the link between the grassroot, the State Governments (Regional) and the Federal Government (Central). A properly managed Local Government system will bring development to the rural areas of the country, train up-coming politicians for participating in national politics and create jobs for the young and the old. Local Governments had existed in Nigeria before colonialism and had continued to be after independence in 1960 where each Region of the country adopted her own system of Local Government until 1976 when the Federal Military Government decreed Unified Local Government System in the whole country. The Constitution of the Federal Republic of Nigeria, 1979 adopted Unified Local Government System in section 7 of the Constitution just as the 1999 Constitution which in section 8 provided for very stringent procedure for the creation of Local Governments amongst other obnoxious provisions which have made nonsense of the possibility of creating new Local Governments.

In the United States of America, there are 89,055(eighty nine thousand and fifty five) Local Governments of different grades just as Brazil has 5,507(five thousand and five hundred and seven) municipalities (local governments) and India over 200,000(two hundred thousand) Panchayats (Local Governments). There are 774(seven hundred and seventy four) Local Governments in Nigeria which came with the 1999 Constitution and ever since, all attempts to create new Local Government by states have failed because of the stringent conditions contained in sections 8 (5) \& (6) and section 9 (3) (4) and section 162 to mention but a few.

In order to bring out all issues in controversy, we shall begin with the meaning of Local Government, the history of the Local Government administration in Nigeria which will cover a brief mention of the period before colonialism, during colonialism (1861 -1960), period after independence (post 1960), introduction of Unified Local Government System in 1976, the provisions of the 1999 Constitution and the coming of the military between 1984 and 1999. We shall dwell on the 1999 constitution and make little comparative references to other established democracies before making our recommendations. 


\subsection{Meaning of Local Government or Local Authority}

The expression "Local Government" or "Local Authority" is nowhere defined in the Nigerian Constitution but it is commonly regarded as the lowest tier of Government in the country. It is usually composed of democratically elected chairman, and councillors who are supposed to serve for a fixed term for urban and rural populace who elected them. The chairman appoints his supervisors who work with him as members of executive while the councillors amongst themselves elect their leaders who function among them as the Legislature. There is also the bureaucratic arm which is made up of civil servants with professional experience in administration, finance, health, education and agriculture who serve as officials of the Local Government in question.

The Black's Law Dictionary defines 'Local Government' as the government of a particular locality such as a city, county, or parish; a governing body at lower level than the state government (Garner, 2004). In the same vein, the Guidelines for Local Government Reforms (1976) in Nigeria defines it as:

Government at local level exercised through representative councils, established by law to exercise powers within areas... has substantial control over local affairs as well as the staff and institutional and financial powers to initiate and direct the provision of services .... and to ensure that local initiative and response to local needs and conditions are maximized, (Mowoe, 2003).

Local Government has also been defined as the system of government of a town or an area by elected representatives of the people who live there, the organization that is responsible for the government of a local area and for providing services, (Hornby, 2015).

Finally, Local Government has been defined as a body charged with the administration of local government. For example a County-Council, District-Council, a London Borough Council or a Parish Council (Woodley, 2005). Though, the Constitution does not define local government or local authority in Nigeria, we can gather from the above that local government refers to the lowest level of government with elected officials who take care of certain conditions peculiar to their localities and they operate below the State Governments, while Local Authorities refer to the bodies that control the affairs of local government.

They vary in sizes and members, from jurisdiction to jurisdiction. In Nigeria for example, there are 774 local governments as listed in Part I and II of the First Schedule to the Constitution of the Federal Republic of Nigeria, 1999 which was initially 768 local councils, whereas in the United States of America, they are 89,055 local governments according to the 2012 Bureau of Census of United States of America.

In Brazil, the number of local governments are 5,507; while in India there are over 200,000 Panchayats (local governments). The population of the councils also vary depending on the geographical size of the area and the population density, save that in Nigeria, a local government is not expected to have a population of less than 150,000(one hundred and fifty thousand) as stipulated in the Guidelines of Unified Local Government System of Nigeria, 1976.

\subsection{Local Government in Nigeria in A Historical Perspective}

The story of local government in Nigeria is rather a chequered one because it has undergone different phases with different nomenclatures. Thus, it has been referred to as "Native Authority", "County Council", "Divisional Council" and "District Council" to mention but few from different parts of the country. This requires long story to be told but since the purport of this paper is to find solutions to the bottlenecks militating against the creation of new local governments in Nigeria, we shall be brief to the point. In doing this, we shall take it in phases that is to say: the situation before the coming of the Europeans, the situation between 1914 and 1960 ; local government during the First Republic, local government during the first phrase of military rule and finally, the position in the 1980s and 1990s.

This brief discussion will enable us to know when the problem of local government started and that will prepare ground for identifying the bottlenecks and possible remedies.

\subsection{The Period Before Colonialism}

Afro-Centric writers and historians hold the view that before colonization of Africa by Europeans, that the country had rich culture and civilization which enabled the people to live in peace and organize themselves very well. In Nigeria, this was very manifest in the government set up by the three (3) biggest ethnic groups in the country namely: Hausa, Igbo and Yoruba. We shall use the three as examples of the historical position before colonization in the $19^{\text {th }}$ Century.

\subsubsection{Hausa-Fulani Political System}

Before the islamization of the diverse geographical area known as Northern Nigeria by Uthman Dan Fodio between 1804-1809, the area was ruled as City-States with monarchical set up. The city states were ruled by kings (Sarkins) who had enormous powers over their subjects. However, between 1804-1809, Fodio overran the 
bulk of the area after his Jihad and established a Theocratic State with headquarters at Sokoto where his son, Bello was based as the leader while the Eastern flank with headquarters at Gwandu was under the control of his younger brother, Abdullahi.

The Fulani Jihadists after the sacking of Hausa kings, reformed the system of government and imposed purely Islamic culture but still maintained Hausa language as the lingua-franca of the caliphate (Onwubiko, 1972). The Jihadists therefore installed their members as kings of the conquered city-states with the title of Emirs and Sultan as the overall head based at Sokoto. The Emirs had their Ministers of State whose titles and functions now assumed Islamic flavour. Some of the old offices under the over thrown governments under the Hausa kings that were retained included such as the Galadima, the Madawaki, the Magaji, the Yauri, the Sarkin Dogarai, Sarkin Yandoka and Alkalis etc who were responsible for different state duties (Onwe, 2012).

Under the Emirs were District Heads who reported to the Emirate Council just as village heads reported to District Heads. The government was therefore stratified with officials at each level knowing their specific functions, all founded on Islamic precepts. This was in brief the political situation in nearly all parts of the present Northern Nigeria (19 states), save that in some areas, that is, the present Plateau State, Taraba State, Benue State and Southern Kaduna of Kaduna State, the Jihadists did not conquer the tribes and they retained their administrative culture of being ruled by their native kinsmen and of course retained their method of worship to God.

\subsubsection{Igbo Political System}

The Igbo people are located in the present day South-East and part of South-South of Nigeria and their style of government was based on Democratic Village Republics and in some places Constitutional Village Monarchies which did not hold large population comparable to what we had in the Hausa and Fulani enclave. The Igbo society was organized and still organized into clans or group of clans known as 'Obodo' which in turn were and are still divided into villages and it was the village that constituted state authority as village was the basis of government. Each village traced its origin to a common ancestor. The government of a village constituted of two major organs: the Council of Elders and the Village Assembly (Onwubiko, 1972). The Council of Elders was constituted of heads of families known as kindreds. The Head of Council was called the 'okpara' who acted as the political as well as the spiritual leader of the village. The 'okpara' held the staff of office known as 'ofo' which was known as the symbol of village authority.

The Village Assembly on the other hand was the supreme organ of the village administration where all important decisions affecting the village were taken and responsibilities for implementation assigned to individuals and groups. Every adult male was a member and had the right to air his views. Meetings were held as frequently as the need arose and the spokesman or chairman changed depending on the issues at stake. At the Assembly, select committees were appointed to go and discuss issues raised and proffer solutions. After the discussion by the committees, it will report back to the Assembly which might accept the report in full or with some amendments. Decisions were arrived at through consensus and not by voting. The playground or market square was usually the venue of the Village Assembly. Thus the Igbos practised a better form of democracy than what had been ascribed to the Greeks of Europe.

Apart from the Council of Elders and Village Assembly, Igbo had age-grade members of both sexes who participated in carrying out one function or the other in the village society. In addition, priests of Oracles played judicial roles as and when necessary just as the 'Umu-Adas' (Daughters of the village) had one function or the other in ensuring peace in the village. The Village Assembly also played major roles in judicial matters as cases were settled by it and difficult ones referred to the priests of Oracles.

In some places in Igbo land, we have constitutional village monarchies in such places as Onitsha where we have the Obi of Onitsha; Arochukwu where we had the Eze of Arochukwu, Asaba where we have the Asagba of Asaba, Agbor where we have the Obi of Agbor and Oguta where we had the Eze of Oguta. These monarchies did not establish governmental structures holding large populations comparable to the Hausa-Fulani. In other words, the Igbo political system was not tailored to large state structure, hence the contention that it was a 'stateless' society but we are saying that the Igbo had a democratic and egalitarian system of government that satisfied their individual and collective interests of before colonialism in the $19^{\text {th }}$ century. No wonder the people had to revolt violently in 1929 when women rioted at Aba and its environs over alien system of government epitomized by the use of Warrant Chiefs as leaders of the people.

\subsubsection{The Yoruba Political System}

The Yoruba like the Hausa Fulani had City-States. At the head of each city-state was the Oba whose powers were checked by a group of nobles known as the Oyomesi. The city had subunits ruled by Bales or lesser Obas. The Ife town was and is still regarded as the cradle of the Yoruba civilization. At the peak of the famous old Oyo Empire between 1388-1431, it was recorded that the highest political leader was the Alaafin of Oyo whose authority covered beyond the present day Yoruba land (Aderibigbe, 1965). The Alaafin had elaborate court of priests, officials and eunuchs. The power of the Alaafin was checked and balanced by a group of nobles call Oyomesi who acted as kingmakers. The chairman of the Oyomesi was known as Bashorun and was regarded as 
the traditional prime minster of the empire.

The Alaafin governed on the advice of the Oyomesi and he could be deposed by the council if he became autocratic or no longer tolerable. This they did by presenting the Alaafin with empty calabash which was symbolic of an order to commit suicide.

The Ogboni cult was another government institution in the old Yoruba and it played the role of mediating whenever there was dispute between the Alaafin and Oyomesi. Thus, the Yoruba had comparable large state structure that could be said to be states in modern sense. It should also be noted that after the fall of the old Oyo Empire, the former component city states formed kingdoms where Obas were the heads with designated state officials while the Bales operated at the village levels. This is in brief the position in Yoruba land before colonization in the $19^{\text {th }}$ century.

\subsection{Between the Amalgamation in 1914 and the $1^{\text {st }}$ Republic, $1960-1966$}

Notwithstanding the initial posture of the British government that it was not interested in territorial expansion of any sort in the $19^{\text {th }}$ century, it had from 1861 started changing its position by the declaration of Protectorates over Northern Nigeria and Southern Nigeria in 1900 (Udoma, 1994). Before this period, these two protectorates were partly under the control of British officials as well as the Royal Niger Company which had its Charter revoked to enable the government take full control of the large enterprise, (Igwenyi, 2006).

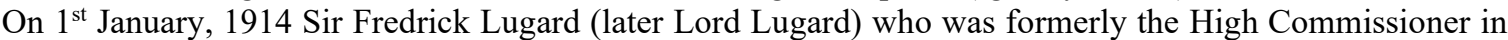
charge of the Protectorate of Northern Nigeria and later was appointed the Governor-General of the Colony and Protectorate of Nigeria united the two protectorates. It should be noted that Sir Lugard had at the inception of his leadership of the Northern Protectorate, introduced a system of government in the area which was known as Indirect Rule following the experience he had at India where he had served as military officer. Indirect rule means a system of government whereby the natives were allowed to rule their people under the supervision of few British officials. There he retained the Hausa-Fulani system of government which he met in the north and used only few British technocrats to supervise them. The reasons for this posture could be attributed to existing good political structure and lack of funds to engage career officers and the need to avoid revolt by the natives.

Having settled down as Governor-General of Nigeria as an entity in 1914, Lord Lugard proceeded to introduce indirect rule in the whole Nigeria. He justified the introduction of his system in his work (Lugard, 1923) which marked the beginning of the real story of modern form of local government in Nigeria. In the year 1916, Lord Lugard signed into law The Native Authority Ordinance which introduced indirect rule system in the whole country arguing that it was meant to protect the political culture of the natives and avoid possible revolt in the future as experienced in India where he had served previously (Okafor, 1981). Thus, the law was applied in the whole Colony and Protectorate of Nigeria as from 1916 and that meant that his experience in Northern Nigeria where he met efficient traditional political system after the conquest of Sokoto caliphate propelled him to believe that indirect rule would work in every part of the unified entity.

The Indirect Rule system succeeded fully in Northern Nigeria especially in areas covered by the defeated Caliphate. It partially succeeded in Western Nigeria because of existing political culture of the area but failed totally in Eastern Nigeria because of the existing independent democratic village republics which saw indirect rule as alien culture. Here in Eastern Nigeria, the colonial power made use of 'Warrant Chiefs' to make up for Emirs in the North and Obas in the West. This was met with resistance culminating in the Aba Women's Riot of 1929 (Onwe, 2012).

Due to nationalistic activities by emerging elites and the improvement in the political and social situation of the people of the colony and the enactment of the Richards Constitution in 1946 and others before it, the consciousness of Nigerians began to build up. Thus in 1950, the government of Eastern Region introduced the Eastern Region Local Government Ordinance which abolished the warrant chief system and introduced what can be called modern local government system. It introduced three layer local government system with Counties at the apex and Districts at the middle and Local Councils as the lowest. Due to operational challenges, County Councils were abolished in 1959(Abba and Nwanne, 2007). In the year 1960, the law was amended and now called Local Government Law, 1960.

It is important to note that it was flexibility and amiability of this system to the people that made it a masterpiece. Section 2 (1) of the law provided that the Minister in charge of Local Governments might establish any of the councils as he deems fit, provided he got the approval of the Governor-in-Council. The minister might designate such councils as municipalities under county councils, districts or local councils, depending on the request from the local area. Over $80 \%$ of the members of these councils were elected by the electorate and the councils had specific functions assigned to them by law which included power to levy taxes. Gold Coast (Ghana) in 1951 copied the Eastern Regional Law on local government just as Western Region of Nigeria did the some in 1952 because of the suitability of the law to their circumstances. It is also worthy to note that between 19221950 local government became a residual item of the Regions and no longer a central government affair. Thus, at the end of the first republic of Nigeria on $15^{\text {th }}$ January 1966, the position on local government can be 
summarized as hereunder stated.

In the Eastern region, the Local Government Law 1960 was operative with three-tier local government system under the supervision of the Regional Government. In the Western Region, the system in operation was three -tier local government system with Division at the apex, followed by District, which might be Urban or Rural and Local Councils. This was because the Region amended the model it copied from the East in 1957. The Mid-Western Region which was carved out from the west in 1963 retained the Western Regional Model of threetier local government whose officials were elected and had some degrees of financial autonomy.

In the Northern Region, notwithstanding the favourable political climate for the use of Native Authority Ordinance of 1916, nationalists activities and changes in the colonial constitutions forced the Regional Government to enact the Native Authority Law 1954, which was amended in 1955, 1958, 1960, 1961 and 1963 (Onwe, 2012). The amendments enabled traditional institutions to work with some level of democratic councils. This was particularly so to take care of agitations by Christian and pagan communities in the North such as the Middle -Belt Tribes in the present day Taraba, Benue, Kwara and Plateau States. Thus, by the changes in the Native Authority Law, the North had such classification as the Chief-in-Council where the Emirs had absolute authority; the Chief -and -Council where the Christians and Pagans are controlled with some form of democracy and lastly the Council which was constituted by tiny villages. Caretaker leaders were appointed by the Regional Government for the Councils at the lowest levels as there were no elections therein. This was the position of local governments nationwide before 1966 and that position was so because local government was a Regional item solely under the control of Regions as second tier partner in the federation.

\subsection{Local Government between 1966 and 1999}

The high points of our discussion here is to state broadly that local governments in Nigeria became major casualty to the quasi-federal system introduced by the military which started with the Constitution (Suspension and Modification) Decree of 1966 which was enacted by Gen. J.T.U Aguiyi-Ironsi, the first military Head of State of the country. The said Decree (now Act) took up all the items from the legislative list and regional leaders (military governors/military administrators) took permission before they legislated on items even in the former residual list meant for the Regions in 1963 Constitution. Thus, regional leaders had no legislative list to act on again because of the incursion by the military in 1966. The local government remained without elected officials (save between 1976-1979) and the designated councils were under the control of career civil servants. However, it have been contended and we agree with that that the local government faired better between 1966 and 1975 under state governments than what became of local governments under the 1976 United Local Government Reforms, the 1979 Constitution and the present 1999 Constitution of the Federal Republic of Nigeria (Onwe, 2012).

Thus, between 1966 and 1975, there was confusion with regard to which form of local government should be applied. In the East-Central State, the government enacted Divisional Administration Edict which created Divisions at the apex, County Councils at the middle and the Community Councils at the lowest level. In the Western and Mid Western States, they tried Professional Management Boards for local governments which failed while in the North, the Native Authority system pervaded with some changes in the Middle-Belt (Abba and Nwanne, 2007). It was not surprising that in 1976, the Head of State, Gen. Olusegun Obasanjo decided to introduce unified reforms in the system of local government administration in Nigeria.

\subsubsection{The Unified Local Government Reforms, 1976}

In 1976, the Federal Military Government under Gen. Olusegun Obasanjo introduced major reforms in local government in Nigeria. The instrument for the reforms was contained in Guidelines for Local Government Reforms 1976 which had the following highlights:

(1) Introduction of a uniformed system of local government in all the states of the federation.

(2) Recognition of local government as a third-tier of government .

(3) Recognition of single-tier all purpose local government council all over the country with the name, Local Government Area.

(4) Prescribing a population size between 150,000-800,000 people for local government councils save in exceptional cases.

(5) Democratization of local governments which led to existence of elected executive branch and elected legislature who worked on full time basis instead of receiving sitting allowances only.

(6) Creation of Local Government Service Commissions in the states to handle civil servants matters.

(7) Limiting the influence of traditional rulers in the local governments.

(8) Preparing of ground for the entrenchment of local government in the 1979 constitution of Nigeria.

(9) The funding of local governments by the federal government through statutory allocations from the federation account.

(10) The first full reform of local government throughout the country by the federal government.

In his foreword to the guidelines, the then Chief of Staff, Supreme Headquarters, Brig. Shehu Musa 
Yar'Adua among other things said that the guidelines were meant for the states to implement and not a sort of imposition; that is was not meant to do away with Emirs, Obas and Chiefs but to bring a fundamental change in the political structure of the Country which will culminate in having a third-tier government that will bring about development in the grassroots. It was also to avoid abuses in the system that the guidelines were issued (Yar'Adua, 1976).

Following the guidelines in local government reforms which came as part of transition to civil rule by the Obasanjo regime, new local governments were created in 1976 and elections held nationwide in all the local governments of the country. Thus, chairmen and vice-chairmen of local government areas were elected to administer the councils, with supervisors as executive arm while councillors were elected to manage the legislature which made laws for the councils. The Military while handing over power to civilians in 1979 introduced local government in the 1979 constitution in the spirit of 1976 Reforms.

\subsubsection{Local Government under the 1979 Constitution}

The Federal Military Government in fulfillment of the spirit of the Local Government Reforms provided in S.7 of the Constitution that this body shall be treated as a third-tier of government and that the states have power to create local councils using the criteria comprised in the Guidelines.

Thus, in section 7 (2) of the Constitution, it is provided as follows:

The person authorized by law to prescribe the area over which a local government council may exercise authority shall:

(a) define such area as clearly as practicable

(b) ensure to the extent to which it may be reasonably justifiable that in defining such area regard is paid to: the common interest of the community in the area.

(ii) traditional association of the community.

(iii) administrative convenience.

Under subsections (3), (4) and (5) of section 7, a local government council in a state shall participate in economic planning and development of the area; shall discharge functions comprised in the Fourth Schedule of the Constitution and shall be governed by elected officials in line with rules guiding National elections. Subsection 6 provided:

Subject to the provisions of this constitution:

(a) The National Assembly shall make provisions for statutory allocation of public revenue to local government council in the federation

(b) The House of Assembly of a state shall make provisions for statutory allocation of public revenue to local government councils within the state.

By this provision, the constitution made provisions for joint funding of the local governments by the federal and state governments.

The 1979 constitution did not concern itself with modalities or procedures for creation of local governments as it did for state's creation in section 8. In the same vein, it merely listed the existing local governments as components of the then existing 19 states and did not mention the number as bar to future creations under the constitution as can be seen in section 3 (1) \& (2) and the first and second column of Part 1 of the First Schedule to the 1979 Constitution unlike what is done in the 1999 Constitution which created problem. In the case of Attorney General Imo State vs. Attorney General Rivers State (1983), it was held that a state government had no barriers to create new local governments under the 1979 constitution.

Another important provision of the 1979 Constitution was the establishment of the 'Federation Account' for the whole country. Subsections (4) and (5) of section 149 provided for Joint State-Local Government Account into which funds meant for local governments in the states shall be paid into for the purpose of sharing such funds amongst them. Under subsection (7) of section 149, the State House of Assembly of each state shall make law on how funds allocated to the state shall be shared among the local governments in the state.

Apart from few constitutional cases that were decided on the issue of power of state governors to constitute caretaker committees for local governments which were all in the negative against governors, the local governments were safely in existence between 1979-1983. It is necessary to note that on $31^{\text {st }}$ December 1983 , there was another coup in Nigeria which ended the Second Republic and the coup was lead by Major Gen. Muhammadu Buhari (the current civilian president). The local governments as listed in the 1979 Constitution remained as the civilians met them but later massive wave of states and local governments' creations took place all over the country under future military officials from $1^{\text {st }}$ January, 1984.

Thus, between $1^{\text {st }}$ January 1984, and August 1985, the country had Major Gen. Muhammadu Buhari as Head of State between $27^{\text {th }}$ August, 1985 and $27^{\text {th }}$ August, 1993 Gen. Ibrahim Babangida as Military President; between August 28, 1993 and 17 ${ }^{\text {th }}$ November, 1993 the country had Chief Ernest Shonekan as interim Head of 
State and between November 18, 1993 and June 8, 1998, Nigeria had Gen. Sani Abacha as the leader with each of them (save Shonekan) tampering with the number of local governments in the country.

Under the Political Transition Programme of Gen. Ibrahim Babangida which spanned between 1986 and 1993, he created more local governments in the country without due regard to the 1976 Guidelines in favour of his Northern Nigeria. For instance, Kano State that had the same population as Lagos State was allotted 44 local governments but Lagos in the South was allotted 20 (twenty) local governments and this shows the degree of bias exhibited by the military leaders who were mostly from Northern Nigeria. Gen. Sani Abacha followed the footsteps of his brother, Gen. Babangida and created more local governments with bias in favour of the states in Northern Nigeria. The result is that out of the 774 (Seven Hundred and Seventy Four) local governments in Nigeria, 355 (Three Hundred and Fifty Five) are in the 17 Southern states while 419 (Four Hundred and Nineteen) are in the North which is sparsely populated unlike the South which is densely populated (Onwe, 2012). That is why on the promulgation of the 1999 Constitution, many Civilian Governors in the Southern States wanted to create local governments to enable them enjoy the benefits attendant in having local governments- more federal financial allocations, more federal and state constituencies and other social amenities. 3.3.3. The Local Governments and the Bottlenecks in Their Creation under the 1999 Constitution.

The 1999 constitution is virtually a replica of the 1979 constitution particularly as it concerns local governments. Like the 1999 constitution, it makes it clear under section 2(2) that Nigeria "shall be a federation consisting of states and a federal capital territory". This puts to rest the argument that both constitutions made the local government autonomous third tier after the federal and state governments. At best, the local governments are statutory and or derivative third tier not intended to be fully independent of the other two senior tiers.

Since the intent of this paper is on the bottlenecks to the creation of new local government in Nigeria, we shall proceed to highlight them, do a small comparative analysis before our recommendations on the way forward.

The first bottleneck in our view is sections 7 and 8 of the 1999 Constitution. Section 7 of the 1999 Constitution contains the same provision as section 7 of the 1999 Constitution by recognizing local governments as a tier of government to be supervised by the States. Section 3 of the same 1979 Constitution also contains almost same provision as section 3 of the 1999 Constitution. Except that in the latter, the Constitution listed 768 local governments thus: "3 (6) there shall be seven hundred and sixty-eight local government areas in Nigeria as shown in the second column of councils as shown in Part II of the Schedule."

By this provision, the local governments are elevated to an integral part of the Union whose personalities cannot be toyed with except through constitutional amendments. This is unlike the situation in 1979 when the local governments were listed merely as components of the respective states under the First Schedule, Part I.

The second bottleneck for local government creation in 1999 is the manner of their creation. Section 7 as already stated empowers state governments to create local governments and nurture them and the actual procedure is as detailed as in section 8 (3) (5) and (6) of the Constitution.

Section 8 (3) provides as follows:

A bill for a law of House of Assembly for the purpose of creating a local government area shall be passed if-

(a) A request supported by at least two-thirds majority of members (representing the area demanding the creation of the new local government area) in each of the following, namely.

(i) The House of Assembly in respect of the area

(ii) The local government councils in respect of the area is received by the House of Assembly;

(b) A proposal for the creation of the local government area is therefore approved in a referendum, by at least two-thirds majority of the people of the local government area where the demand for the proposed local government area originated;

(c) The result of the referendum is then approved by a simple majority of the members in each local government councils in a majority of all the local government councils in the state.

(d) The result of the referendum is approved by a resolution passed by two-thirds majority of members of the House of Assembly.

The above stipulation which is easily achievable by a state in need of more local governments is hampered by section $8(5)$ which states:

An Act of the National Assembly passed in accordance with this section shall make consequential provisions with respect to the names and headquarters of states or local government areas as provided in section 3 of this constitution and in Part I and II of the First Schedule to 
this constitution.

Complicating issues further, section 8(6) provides:

For the purpose of enabling the National Assembly to exercise the power conferred upon it by subsection (5) of this section, each House of Assembly shall after the creation of more local government areas pursuant to subsection (3) of this section make adequate returns to each House of the National Assembly.

The Implication of the above is though states can create local governments, the exercise shall not be complete until the National Assembly makes approval which will entail ratification of the names of local governments and their headquarters for the purpose of listing them in the constitution. This is perhaps the greatest constraint on local governments in Nigeria which has led to plethora of litigations in the country since 1999 when some states created local governments in their domains and the National Parliament for political reasons, refused to play its own part.

The most cited case in connection with dispute over local government creation is that of Attorney General Lagos State v. Attorney General Federation (2004) where the powers of the most senior tiers were outlined. The brief facts of this case being that the Lagos State government relying on section 8(3) of the Constitution created 37 (thirty seven) new local governments out of the existing 20 (twenty) local governments thereby bringing the number of local governments in the state to 57 (fifty seven). The state went ahead to conduct elections into the old and new councils even when the National Assembly had not acted pursuant to section 8 (5) and (6) and section 3 (6) of the Constitution. The federal government directed the Lagos state government to reverse back to the old 20 local governments, arguing that the existence of 37 new local councils was unconstitutional. It threatened to seize funds allocated to the local governments in the state and in fact, carried out its threat. The Lagos state government approached the Supreme Court for judicial intervention and so many legal principles came out from the case. Chief among the decisions of the court being that the 37 new local governments created by the state government were yet to be fully so as the National Assembly had not enacted its own consequential Act as required by section 8 (5) and (6) to bring them into existence; that the Local Government Law No 52002 of Lagos State passed by the House of Assembly was not enough to give life to the new local councils until section 3 (6) of the Constitution was amended to include them in Part I of the First Schedule to the Constitution and that for a state to receive funds pursuant to section 162 (3) and (5), such local governments must be legally and constitutionally created and finally that the action of the President in withholding statutory financial allocations belonging to Lagos State was not proper as he ought to approach the court for interpretation of the legal position.

The Lagos State government case prompted other states that had created local governments without the input of the National Assembly to change their nomenclatures to either Development Areas or Development Centres to avoid the bitter experience of Lagos State government.

Commentators have roundly condemned the decision of the federal government in the way it handled Lagos state's case as if it was the only state that created new local governments under the 1999 constitution. The result of this case is that it created constitutional crises and no new local governments have been 'duly' created under the constitution. But many states now have what they designate as Development Areas or Development Centres to avoid the Lagos state experience.

Another impediment to the creation of local governments in Nigeria is the issue of funding of the councils as stipulated under section 162 of the Constitution. Section 162 creates the 'Federation Account' for the purpose of sharing National revenue among the federal, states and local governments. Section 162 (5) provides that funds standing to the credit of local governments in a state shall be allocated to such state for distribution to local governments therein. Each state shall maintain a 'Joint State-Local Government Account' into which shall be paid all allocations to the local government councils of the state from the federation account and from the state governments. Under subsection (6), the House of Assembly of each state shall make law on criteria for sharing the money among the local governments in their respective states.

The major implication of section 162 (5) and (6) is that a local government that is created under section 8 (3)(5) and (6) and it is not listed in the schedule under section 3 (6) cannot be allocated funds either by federal or state governments. Complicated also in this instance is that to accommodate a new local government in the list, the constitution requires amendment under section 9 which requires two-third majority of both Houses of the National Assembly as well as two-third majority of the 36 (thirty six) States Houses of Assembly in the country. This is the crux of the matter and we need to make a peep into other jurisdictions before we make our recommendations.

\section{Comparative Look at Other Jurisdictions 4.1. United States of America}

In the United States of America, from where Nigeria copied the President system, local government started as 
Community Civic Republics and Community Enterprises to serve group interests (Ohiole and Ojo, 1999). Later on, these entities started getting charters from state governments to enable them render one service or the other to their immediate environment.

In the United States, there are in existence 4(four) types of local governments namely: county governments, town or township local governments, municipal local governments and special purpose local governments. Under the Tenth Amendment of the U.S.A Constitution, local governments are matters for States and the result is that from the Census Bureau, USA 2012 indicates that there are 89,055 (eighty nine thousand, and fifty five) local governments in the USA with different nomenclatures and sizes all under the state governments. These local governments generate their own income and are partly supervised by their states and they have their financial autonomy to a reasonable extent and that shows a functional federal system unlike the position in Nigeria where we have Unified and one pattern form of local governments with the states tampering with funds allocated to the local governments. Again, the population of U.S.A is above the same with that of Nigeria and the gap between the number of local governments in the two countries cannot be justified for whatever reason.

\subsection{Brazil}

In Brazil, the country operates a federal system with three-tier government structure as contained in the 1988 Constitution of Brazil (Akinlabi, 2017). There are 26(twenty six) States in Brazil, each with her Constitution, Governor and Legislature. There are a total of 5,507(five thousand five hundred and seven) municipalities (local governments) which are further divided into districts. Each municipality has its own elected mayor and municipality. Each state has a minimum of 214 (two hundred fourteen) municipalities. The states and municipalities are subordinate to the federal government while the municipalities are created under the control of the state governments.

\subsection{India}

India is another country running a three-tier federal system with states and Panchayats (local governments) as the second and third-tiers respectively. By the $73^{\text {rd }}$ and $74^{\text {th }}$ amendments to the Indian Constitution 1993, the Panchayats became official third-tier level of government in the country (Mathew, 2017). Commenting on the effect of the Indian Constitutional amendment 1993, Mathew stated:

First, the democratic base of the India polity has widened. Before the Amendments, the democratic structure of the India through elected representatives was restricted to the two Houses of Parliament, 25 State Assemblies and two assemblies of the Union Territory... They had just 4,963 elected members. Now there are more than 589 District Panchayats, 6,904 Block/tehsil/Mandal Panchayats at intermediate level and 239,000 gram Panchayats in rural India where about 72 percent of India's population lives.

The point we are making is that local governments in India as at December $12^{\text {th }} 2015$, were about 246,493 (Two hundred and forty six thousand four hundred and ninety three) in both urban, intermediate levels and rural areas. The 25 (twenty five) states and the federal government contribute however, to their sustenance as third-tier of government and the Panchayats are under the states as residual item.

Thus, we can see that in the three large democracies we have studied, the local government constitutes residual item under the states and that is why they are in thousands because their creations are not limited and their control not centralized as in the Nigerian situation.

Also observed in the large democracies studied is that the local governments are not uniform. There are of different sizes and have different purposes as in the case of the U.S.A and the central authority has no input in their creation. We can see that that was the purpose of the Unified Local Government Reforms 1976 which pegged the population of local governments to a minimum of 150, 000 (one hundred and fifty thousand) and a maximum of 800,000 (eight thousand) persons which was ignored by the military leaders and bastardized the system and imposed the 1999 Constitution on $29^{\text {th }}$ May 1999 while they were leaving office with the bottlenecks highlighted herein before.

\section{Conclusion and Recommendations}

In the light of the fact that the bottlenecks affecting the creation of local government in Nigeria are constitutional, our first suggestion is that the constitution should be amended as follows:

First. the creation of local governments and its management as provided under section 7 of the Constitution should not be made subject to section 8(5) and (6) of the Constitution. That is to say that once a state creates a local government under section 8 (3) of the Constitution it should no longer be subjected to National Assembly. That will mean that subsections (5) and (6) of section 8 which requires the National Assembly to ratify local governments created by the States, should be expunged from the Constitution so that where a state creates a local 
government whose population is a minimum of 150,000 persons and maximum of 800,000 persons, the entity should be entitled to all privileges and rights of a local government in the country.

Second, section 3(6) of the Constitution should be amended to remove the pegging of the number of local governments in Nigeria to a particular figure which will require constitutional amendment before new local governments will be added after creation. This will enable the States to create as many local governments as possible because of the propensity to spread grassroots development nationwide. Thus, when a State creates new local government in conformity with the law, the states will forward the name(s)to the Federal Revenue Allocation Committee for recognition and listing for the purpose of receiving funds from the Federation Account

Third, that section 162 (5) \&(6) of the Constitution creating Joint State-Local Government Account should be expunged from the Constitution to allow each local government in each State to receive its fund directly from the Federation Account no matter how small. A situation where the State governments receive their money and tamper with them is detrimental to the existence of these councils in Nigeria.

Four, again, it is our thinking that if the aforementioned amendments are made and more powers devolved to the local governments from the legislative list that local governments in Nigeria which is a country having a population of over 200 million will contribute to the development of the countryside and improve the well being of the people generally. U.S.A with a population of almost the same size as Nigeria boasts of about 90,000(ninety thousand) local governments while Nigeria has only 774 (seventy-seven thousand four hundred). This should not be if Nigeria wants to move with other progressive counties in the world.

Finally, what is happening in Nigeria is against the principle of federalism. Under a federal system, each federating unit is supposed to develop at its own pace based on the various diversities of the entire country. Which means that each of the States in Nigeria ought to be allowed to develop its own type of local government administration and not to be forced to adopt the current one-layer form of local government which doesn't allow any State to apply its peculiarities in creating local governments or classifying local governments within its territory. In this wise, we still suggest that States in Nigeria should be given total power to run the type of local government system convenient to them.

\section{References}

Abba U.E. and Nwanne V. (2007) Local Government Administration in Nigeria (Laws and Practice), Abbot Books Ltd, Onitsha Pp. 76-77.

Aderibigbe A.A.B. (1965) "Peoples of Southern Nigeria" in Ade Ajayi J.F and Espie .I. (eds.) A Thousand Years of West Africa History, Thomas Nelson Nig. Ltd, Lagos Pp.193-195.

Akinlabi A. (2017), "Independence of Local Governments, Full Autonomy and the Proposed Autonomy" https://www.thenigerianvocie.com/news/164712/1/independecne-of-local-governments-fullautonomyan.html $>$ accessed on March 22, 2017 by $2 \mathrm{pm}$.

Federal Military Government, (1976) Guidelines for Local Governments Reform, Government Printer, Kaduna.

Garner, B.A. (2004),(ed), Black's Law Dictionary, $9^{\text {th }}$ Edition, West Publishing Company, Dallas Texas, P. 764.

Hornby, A. S. (2015) Oxford Advanced Learner's Dictionary, Oxford University Press, Oxford. P. 915 http://www.census.gov/govs/cog2012> accessed on March 22, 2019 by $10 \mathrm{pm}$.

Igwenyi, B.O. (2006) Modern Constitutional Law in Nigeria, Nwamazi Printing and Publication Company Ltd, Abakaliki.

Lugard, F (1923) Dual Mandate for British Africa, William Blackwood and Sons Ltd, London, Pp. 219-220, 228-229.

Mathew, G. (2017) "Local Government System in India" www.pildat.org/publication/FP/local government system in India-Background paper pdf $>$ accessed on 24/3/2019.

Mowoe, K. (2003), Constitutional Law in Nigeria, Malt House Press Ltd, Lagos Pp. 193-194.

Municipalities of Brazil-Wikipedia <http://en.m.wikipedia.org>wiki>municipalities-of-Brazil $>$ accessed on $14 / 9 / 2019$ by $8: 55 \mathrm{pm}$.

Okafor, S.O. (1981) Indirect Rule (The Development of Central Legislature in Nigeria) Thomas Nelson Nigeria Ltd, Lagos, Pp. 37 -38.

Ohiole, K.O. and Ojo, S.I. (1999) "Local Government Autonomy and Democratic Governance: A Comparative Analysis of Nigeria and United States of America" https:/www.arabianjbmr.co./JPDS-vol-9-1/4.pdf> accessed on March 22, 2019.

Onwe, J.O. (2012) The Dilemma of Operating Nigerian Local Government System Under the 1999 Constitution, Snaap-Press Nigeria Ltd, Enugu, Pp. 15-16.

Onwubiko, K.B.C. (1972) History of West Africa, Book II, African Educational Publishers, Nigeria Ltd, Onitsha, Pp. $107-112$.

Stride, G.T. and Ifeka, .C. (1971) Peoples and Empires of West Africa, West Africa in History (1000-1800), Thomas Nelson Nigeria Limited, Lagos, Pp. 86, 133, 288 and 346.

Udoma, U. (1994) History and Law of the Constitution of Nigeria, Malt-House Press Ltd. Lagos, Pp. 23-25. 
$<$ U.S. Census Bureau 2012 Census of Government

Woodley, .M. (2005), Osborne's Concise Law Dictionary, 10 ${ }^{\text {th }}$ Edition Sweet and Maxwell, London. P. 250.

A.G. Imo State vs. A.G. Rivers State (1983) 14 NSCC 370

A.G. Lagos state vs. A.G. Federation (2004) ALL FWLR Pt 244 p.805 S.C. See also A.G. Abia State \& 35ors vs. A.G. Federation (2002) 6 NWLR Pt. 763 p. 264. 